\title{
Enquete: Ratsinalisering
}

Danskerne kan selv - og kan ikke selv. På den ene side er de nærmest anarkistisk egenrådige og tøver ikke med at trodse deres lederes anbefalinger, hvilket flere EU-afstemninger har vidnet om. På den anden side er de autoritetstro, hvilket for eksempel en generel accept af verdens højeste skatteprocent (samt et væld af indirekte skatter) vidner om. Hvorledes forklarer man denne selvmodsigelse i dansk identitet?

Jeg har i forbindelse med mine historiske studier af livet i de danske landdistrikter 1800-2000 interesseret mig for fænomenet. Selvmodsigelsen synes at tage form i sidste halvdel af 1800-tallet, det vil sige i de store, folkelige bevægelsers tid. Som for eksempel H. P. Clausen har gjort opmærksom på, finder vi her side om side med en liberalistisk orienteret selvorganisering et udbredt ,høvdinge-syndrom“, der fører til ,,de fås styring af de mange“ (Clausen 1973:11). En sådan høvdingedyrkelse i form af en næsten grænseløs tillid til lederne finder vi inden for den grundt-vigianske højskolebevægelse efter 1864 samt inden for de politiske partier i slutningen af århundredet. Fra omkring 1900 synes lederdyrkelsen endvidere helt at gennemtrænge den ellers traditionelt så autoritetsfjendske andelsbevægelse. Det er de store „,andelshøvdinges“ tid, og her tænker jeg ikke mindst på Severin Jørgensen og Anders Nielsen. Opkomsten af et vel-færdssamfund fra omkring 1960 har yderligere medvirket til at knytte almindelige danskere i et afhængighedsforhold til de politiske ledere og andre medlemmer af Ekspert-Danmark - og dog. Og dog...

Jeg vil her give et par konkrete, historiske eksempler på selvmodsigelsen i dansk identitet. Først vil kan selv-elementet blive belyst gennem en debat, der foregik indenfor De danske Ungdomsforeninger omkring 1920. Herefter vil kan ikke selv-elementet blive belyst gennem et eksempel på en lokal ,indoptagelse“ af den propaganda, der fra topledernes side indledtes inden for andelsmejeribevægelsen fra omkring 1960.

\section{Angrebene på 25-øren}

Ungdomsforeningerne på landet blev ligesom skytteforeningerne og de politiske foreninger dannet i forbindelse med 1880'ernes politiske røre som led i en generel selvorganisering blandt landbobefolkningen. De før-ste blev stiftet af tidligere højskoleelever og blev bredt opfattet som en slags højskoler i det små. Begyndelsen blev gjort på Tåsinge i 1887 , hvor formålet var ,,at samle de unge til Værn om det danske Folks grundlovs-mæssige Frihed og at dygtigg øre dem til at opfylde deres Borgerpligter" (Jensen 1944:81). Den 5. januar 1903 oprettedes den landsdækkende sammenslutning De danske Ungdomsforeninger (D.d.U.). De 
enkelte lo-kalforeninger under D.d.U. skulle få meget stor betydning for kulturlivet ude i landdistrikterne, først som foredragsforeninger, senere op gennem 1960'erne tillige som arrangører af dilettant, baller, gymnastik, diskus-sionsklubber, filmforevisning og så videre.

Lige fra starten var de lokale ungdomsforeninger stærkt præget af lokal forankring og ønsket om selvstyre. Det var således med en vis betænkelighed, man oprettede den landsdækkende samvirkeforening D.d.U., som man bestemt ikke ønskede at tildele mere magt end højst nødvendigt. Denne udvikling kan synes bemærkelsesværdig set på baggrund af udviklingen inden for andelsbevægelsen, hvor samvirkeforeningerne netop fra omkring 1900 fik stadig mere magt på bekostning af lokalforeningerne (se Svendsen under udgivelse). Hvor åben modstand mod centralisering - kaldet „socialisering“ og ,funktionarisme“ - inden for andelsbevægelsen kun blev ført af nogle få andelskættere (Svendsen 2000), var den til gengæld massiv inden for ungdomsforeningerne.

Denne modstand opstod første gang i 1909, da formanden og forretningsudvalget ville påbyde alle foreninger at holde D.d.U.'s tidsskrift Dansk Ungdom. Det ,gik ikke stille af, og der var en Del Foreninger, der enten selv udmeldte sig eller blev udelukket, fordi de ikke opfyldte dette Krav“ (Eller 1928:20). „Det var en usund Foretagsomheds Aand, der var faret i Styrelsen," sagde man (ibid.). I 1918 blussede debatten op på ny, da lokalforeningernes pengetilskud til sammenslutningen blev forhøjet fra 5 til $10 \varnothing \mathrm{re} \mathrm{pr}$. medlem. I 1924 blev det endnu en gang forhøjet til $25 \varnothing \mathrm{re}$, hvor det blev op gennem 1920'erne ,,trods mange og hvasse Angreb på ‘25 Øren"“ (op.cit.:18). Der herskede, som det siges, „,nogen Misfornøjelse“ over at betale til dette ,tungtvirkende Apparat" af repræsentantskab og bestyrelse, hvis nytte man havde svært ved at få øje på (ibid.). Konsekvensen blev, at en del foreninger enten selv udmeldte sig eller blev ekskluderet på grund af manglende betaling (op.cit.:18-19).

Det var specielt et typisk træk i de vestjyske foreninger, at de vendte sig mod sådanne [fælles-]opgaver, ligesom de protesterede mod en stærkere landsorganisation. Det bet $\varnothing$ d også, at de var imod kontingentforh $\varnothing-$ jelser i D.d.U [...] [H]ver gang var der protester, ikke mod beløbet i den forstand, men mod de aktiviteter, D.d.U ville bruge det forøgede kontingent til (Bruhn 1979:52).

Dog havde de selv inden for D.d.U. deres „Høvding“, nemlig den mangeårige formand Mads Ring (Eller 1928:17).

\section{„Ratsinalisering“}

Fra og med Anden Verdenskrig forvandlede høvdingedyrkelsen sig imid-lertid til ekspertdyrkelse. Et godt eksempel herpå er andelsbevægelsens ledere, der - udstyret med propagandaorganet Andelsbladet - op gennem 1960'erne nærmest holdningsbearbejdede de menige medlemmer til at stemme for sammenlægninger og organisatorisk centralisering. Særligt 
sognemejeriet - det lokale kraftværk inden for det $\varnothing$ konomiske liv - havde man været stolt af ude i landdistriktssamfundene. Nu sagde andelslederne, at det skulle bortrationaliseres. Alt andet tolkede de som „lokalpatrio-tisme“, „,bagstræv“ og „forloren romantik“. De lokale mælkeleverandører førte et tavst oprør et par år - så gav man efter. Som en direkte følge heraf faldt antallet af mejerier fra 1127 i 1961 til 280 i 1971. Tendensen er fore-løbig kulmineret i dannelsen af mastodonten Arla i 1999.

Det er faktisk utroligt at tænke sig, at abstrakte, akademiske ekspert-begreber som ,,rationalisering“, ,,strukturændringer“" og ,,vertikal integration" i løbet af et enkelt tiår faktisk blev til ren og skær virkelighed for den almindelige, danske landbruger. Et strålende eksempel på det, Bourdieu har benævnt naming, forstået som „classification struggles“, hvor de sejrende begreber skaber folks virkelighed og herved kommer til at styre deres praksis (se for eksempel Bourdieu 1989:479ff.).

Således også på det lille andelsmejeri i Agerskov i Sønderjylland, hvor referenten ved en ekstraordinær generalforsamling 10/6 1963 nedskrev, at „det ikke var Fussionens agt straks at sætte Tankbiler ind“ (Agerskov Andelsmejeri). Kunne manden ikke stave? Jo, det kunne han faktisk. Det kan man se ud af de andre referater, han lavede. Stavefejlen synes nærmere at bunde i, at et senere så magtfuldt og udbredt begreb som „fusion“ var ham ret ukendt på dette tidspunkt. På nabomejeriet i Rangstrup var det imidlertid et andet magtfuldt begreb i svøb, der voldte referenterne problemer - „rationalisering“ - et ord, der ifølge foreningsprotokollen optræder 8 gange fra 28/10 1960 til den sidste generalforsamling 8/4 1964 . Ved generalforsamlingen 28/10 1960 anførte referenten således følgende: „Anton Holm ønsker ratsinalisering af mejerierne og mente, at mejerierne var alt for smaa, al salg skulde og burde være paa faa Hænder" (Rangstrup Andelsmejeri). I referatets sidste sætning dukker det mærkelige ord op igen, men allerede her havde referenten lært at stave til rationalisering. Det havde en anden referent til bestyrelsesmødet 28/3 1962 imidlertid ikke: to gange skrives der ,rationaliserring“.

De sidste fire gange, ordet optræder i Rangstrup andelsmejeris protokol, havde alle referenter dog lært at stave det rigtigt. Rationalisering var så sandelig blevet virkelighed!

Gunnar Lind Haase Svendsen, ph.d.-studerende Institut for Granseregionsforskning, Aabenraa

\section{Litteratur}

Agerskov Andelsmejeri

Forhandlingsprotokol. Foreningsarkiv nr. 399/3. Det Sønderjyske

Landsarkiv, Aabenraa.

Bourdieu, Pierre

1989 [1979] Distinction: A Social Critique of the Judgement of Taste. London: Routledge. 
Bruhn, Verner

1979 Plint og talerstol. Træk af gymnastik- og ungdomsforeningernes historie i

Ribe Amt. Esbjerg: Ribe Amts Gymnastik- og Ungdomsforeninger.

Clausen, Hans Peter

1973 Hvor længe varede det 19. århundrede kulturelt? I: S. Jørgensen (red.):

Kulturelle, politiske og religiøse bevægelser i det 19. århundrede. Århus:

Det Lærde Selskabs Publikationsserie.

Eller, Edvard

1928

Træk af Historien 1903-1928. I: De danske Ungdomsforeninger i

femogtyve Aar. Odense: De danske Ungdomsforeninger.

Jensen, J. M.

De danske Ungdomsforeninger. I: Bukdahl \& Jensen (red.): Fri Ungdom.

Dansk folkeligt Ungdomsarbejde. Odense: Forlaget Arnkrone.

Rangstrup Andelsmejeri.

Forhandlingsprotokol. Foreningsarkiv nr. 437/4. Det Sønderjyske

Landsarkiv, Aabenraa.

Svendsen, Gunnar L. H.

$2000 \quad$ Centralisering eller lokalisering? Om skvadronøren Knud Thøgersen fra

Kringelkøbing og andre kættere inden for andelsbevægelsen 1900-1914.

Tidsskrift for Landøkonomi 3:241-6.

under udgiv. De danske Ungdomsforeninger og kampen mellem land og by. Fortid og Nutid. 